Research Article

\title{
Genetic Diversity in Cotton Germplasm using Multivariate Analysis
}

\section{Syed Asif Imran Shah ${ }^{1 *}$, Shah Jehan Khan ${ }^{2}$, Kalim Ullah $^{1}$ and Obaid Ullah Sayal ${ }^{2}$}

\author{
${ }^{1}$ The PCCC, Cotton Research Station, Dera Ismail Khan, Pakistan; ${ }^{2}$ Faculty of Agriculture, Gomal University, Dera \\ Ismail Khan, Pakistan.
}

Abstract | Sixty four upland cotton genotypes were investigated for genetic divergence regarding yield related attributes, seed cotton yield and fibre quality traits using principle component analysis. The experiment was carried out at Cotton Research Station, Deara Ismail Khan, Pakistan during 2014-15. The triplicated randomized complete block design was followed and attributes of interest were plant height, monopodia plant $^{-1}$, sympodia plant ${ }^{-1}$, bolls plant ${ }^{-1}$, plant population, seed index, boll weight, lint index, staple length, lint $\%$, fibre fineness,staple strength, uniformity ratio and seed cotton yield. The analysis of variance depicted significant $(\mathrm{P}>0.01)$ genetic variability among cotton germplasm. Highest and close symmetry between phenotypic and genotypic coefficient of variances while lower values of environmental coefficient variance were observed for all the studied attributes which reflected that these traits were genetically controlled and under less influence of environment. Higher broad sense heritability and expected genetic advance reflected that all attributes were governed by additive genes and early phenotypic selection for their improvement might be effective. Five principle components (PCs) were depicted having Eigen value $>1$ and cumulative variability of 78.66\%; PC1 (37.19\%), PC2 (12.94\%), PC3 (11.62\%), PC4 (9.60\%) and PC5 (7.32\%) of variability. The attributes of significance depicted in PC1 were seed cotton yield, seed index, lint index, sympodia plant ${ }^{-1}$ and bolls plant ${ }^{-1}$ divulged great contribution towards total variability. Score plot revealed that Baghdadi, CIM 622, SLH 8, BH 184, Sitara 008, CEMB 66, Leader 5, Cyto 178, FH Lalazar, CRIS 600, AA 703 and Sitara 009 were resulted as most divergent germplasm. These genetically diverse genotypes with absolute and significant association of attributes could be utilized in future cotton breeding program.

Received | October 04, 2017; Accepted | December 31, 2017; Published | February 14, 2018

*Correspondence | Syed Asif Imran Shah, The PCCC, Cotton Research Station, Dera Ismail Khan, Pakistan; Email: iasif99@yahoo.com

Citation | Shah, S.A.I., S.J. Khan, K. Ullah and O.U. Sayal.2018. Genetic diversity in cotton germplasm using multivariate analysis. Sarhad Journal of Agriculture, 34(1): 130-135.

DOI | http://dx.doi.org/10.17582/journal.sja/2018/34.1.130.135

Keywords | Genetic variability, Heritability, Genetic advance, Principle component analysis

\section{Introduction}

$\mathrm{C}$ otton (Gossypium birsutum L.) also termed as "White Gold" is premier fibre and cash crop, widely grown to sustain national economy through earning huge foreign exchange (Haidar et al., 2012). As breeding is an evolutionary process, conservation of genetic stock in the shape of best performing cultivars, breeding lines and wild races are the most substantial factors in any crop (Latif et al., 2015). The basic principle of cotton breeding is continuous improve- ment in genetics of the available plant germplasm for creation of new genetic recombinant with objectives of seed cotton yield potential per unit area having acceptable fibre quality under varying agro-climatic conditions (Ali and Khan, 2007). Genetic variability focused on numerous agronomic and morphological attributes and their interaction with surrounding biotic and abiotic factors has been exploited for future improvement in cotton breeding (Liaqat et al., 2015). The magnitude and nature of obtainable genetic variability among the germplasm has sufficient scope March 2018 | Volume 34 | Issue 1 | Page 130 
to utilize in successful breeding program for improvement of various attributes (Ahsan et al., 2015).

The heritability estimated in broad sense and expected genetic advance estimates enable the cotton breeder in execution of early generation phenotypic selection procedure for numerous attributes which outcome in remarkable response of selection (Vineela et al., 2013), and reflected the preponderance of additive genetic effects controlling various attributes (Reddy and Reddy, 2016). The information regarding genetic variability, heritability and genetic advance existing in the material is significant essential in bordering any crop improvement programme (Reddy and Reddy, 2016). Seed cotton yield and fibre quality depend on sympodia and monopodia plant ${ }^{-1}$, bolls plant ${ }^{-1}$, seed index, boll weight, lint index and ginning out-turn and their association with yield has utmost importance (Latif et al., 2015). Principal component analysisis used to evaluate the relationship and variability among numerous germplasm for their utilization in future cotton improvement programme (Saeed et al., 2014a; Rehman et al., 2015).

Effective varietal selection has significantly been underlined for the preservation of genetic resources along with reliable variability of desired features (Ahmad et al, 2015). Keeping in view the significance of genetic diversity, the present research was conducted to explore the genetic divergence and relationship among cotton germplasm for yield, and yield and fibre quality attributes.

\section{Materials and Methods}

A field experiment was carried out at Cotton Research Station, Dera Ismail Khan (situated at $70{ }^{\circ} 55^{\prime}$ E longitude and 31'49' $\mathrm{N}$ latitude) during the crop season 2014-15.

\section{Experimental layout and crop management}

Sixty four cotton genotypes were raised in randomized complete block design (RCBD) with 3 replications. Sowing was completed with a spacing of 0.75 $\mathrm{m}$ between and $0.30 \mathrm{~m}$ within the hills. The size of plot was $3 \times 3 \mathrm{~m}^{2}$. About $60 \mathrm{~kg} \mathrm{ha}^{-1}$ of phosphate fertilizer as single super phosphate $\left(18 \% \mathrm{P}_{2} \mathrm{O}_{5}\right)$ and $50 \mathrm{~kg} \mathrm{ha}^{-1}$ of nitrogenous fertilizer as urea $(46 \% \mathrm{~N})$ in split doses were applied prior to sowing. Seeds were sown in hills and about 5 seeds were placed in each hill. After sowing the field was immediately irrigated.
About $50 \mathrm{~kg} \mathrm{ha}^{-1}$ nitrogenous fertilizer as urea $(46 \%$ N) used in split doses each at flowering and boll formation stages. After 3 weeks of sowing, thinning was done at seedling stage with objective of single plant per hill. Picking of matured bolls was finalized in 130 and 150 days after sowing. All the recommended management practices for better crop growth were accomplished during the experiment.

\section{Data recording and statistical analysis}

Data were recorded for fibre quality, yield and yield related attributes, viz., plant height $(\mathrm{cm})$, monopodiaplant $^{-1}$, sympodiaplant ${ }^{-1}$, bolls plant ${ }^{-1}$, boll weight $(\mathrm{g})$, lint index $(\mathrm{g})$, seed index $(\mathrm{g})$, lint $\%$ (GOT), staple length $(\mathrm{mm})$, uniformity ratio, fibre fineness $(\mu \mathrm{g}$ inch $\left.^{-1}\right)$, staple strength $\left(g\right.$ tex $\left.^{-1}\right)$ and seed cotton yield $\left(\mathrm{Kg} \mathrm{ha}^{-1}\right)$. The recorded data were subjected to analysis of variance (ANOVA) technique as proposed by Steel et al. (1997). The genotypic and phenotypic variances were calculated using the techniques of Lush (1940). The genotypic and phenotypic coefficients of variances were estimate daccording to Burton (1952). Estimates of heritability in broad sense was evaluated using the procedure of Hanson et al. (1956). Expected genetic advance was assessed using the formula of Falconer (1989). Principal component analysis was estimated according to Kaiser (1960) based on principle of eigenvalue-one criterion or Kaiser criterion.

\section{Results and Discussion}

\section{Genetic variability and heritability}

The mean sum of squares, genotypic $(\mathrm{GV})$, environmental (EV) and phenotypic (PV) variances, genotypic coefficient $(\mathrm{GCV})$, environmental coefficient (ECV)and phenotypic (PCV) coefficients of variation, heritability in broad sense $\left(\mathrm{h}^{2}\right)$ and expected genetic advance(GA) in percentage of means were ascertained for fibre quality, yield and yield related attributes. The estimates of mean sum of squares depicted highly significance variation $(\mathrm{P}<0.01)$ among the germplasm for all studied attributes (Table 1 ). All the studied attributes showed higher $\mathrm{h}^{2}$ (ranged from 79.93 to 99.69) and GA estimates (ranged from 0.80 to 9154.71$)$. GV estimates ranged from 0.15 to 20056171, while PV estimatesranged from 0.16 to 20367658. GCV estimates ranged from 1.87 to 36.57 , while PCV estimates ranged from 1.91 to 40.91, reflected close symmetry with each other for all studied attributes (Table 2). 
Table 1: Analysis of variance (ANOVA) for yield and yield attributes in cotton genotypes.

\begin{tabular}{|c|c|c|c|c|c|c|c|c|}
\hline \multirow[t]{2}{*}{ Source } & \multirow[t]{2}{*}{ d.f } & SCY & PH & PP & MP & SP & BW & BP \\
\hline & & \multicolumn{7}{|c|}{ Mean squares } \\
\hline Replications & & 121983 & 1198 & 5310833 & 1.63 & 8.5 & 0.02 & 9.58 \\
\hline Genotypes & & $747585^{* *}$ & $1352^{* * *}$ & $60480000^{* *}$ & $1.93^{* *}$ & $34.3^{* * *}$ & $0.47^{* *}$ & $40.9^{* *}$ \\
\hline Error & & 776 & 53 & 311487 & 0.15 & 0.23 & 0.00 & 0.13 \\
\hline \multirow[t]{2}{*}{ Source } & \multirow[t]{2}{*}{ d.f } & SL & FS & LP & MV & UI & SI & LI \\
\hline & & \multicolumn{7}{|c|}{ Mean squares } \\
\hline Replications & & 6.03 & 12.9 & 16.2 & 0.98 & 18.6 & 6.58 & 0.76 \\
\hline Genotypes & & $3.66^{* *}$ & $7.7^{* *}$ & $4.8^{* * *}$ & $0.56^{* *}$ & $7.0^{* *}$ & $3.10^{* *}$ & $0.60^{* *}$ \\
\hline Error & & 0.07 & 0.1 & 0.1 & 0.01 & 0.1 & 0.05 & 0.01 \\
\hline
\end{tabular}

**: Significant at 1\% level; d.f: Degree of freedom; SCY: Seed cotton yield; PH: Plant height; PP: Plant population; MP: Monopodia plant ${ }^{-1}$; SP: Sympodia plant ${ }^{-1}$; BW: Boll weight; BP: Bolls plant ${ }^{-1}$; SL: Staple length; FS: Fibre strengtb; LP: Lint \%; MV: Micronaire value; UI: Uniformity index; SI: Seed index LI: Lint index.

Table 2: Estimation of genetic $(G V)$, environmental (EV), phenotypic variances $(P V)$, genotypic coefficient $(G C V)$, environmental coefficient (ECV), phenotypic coefficient $(P C V)$ of variances, heritability $\left(h^{2}\right)$ and expected genetic advance (GA) in cotton germplasms.

$\begin{array}{lllllllll}\text { Traits } & \text { GV } & \text { EV } & \text { PV } & \text { GCV } & \text { ECV } & \text { PCV } & \mathbf{h}^{2}(\mathbf{\%}) & \text { GA (\%) } \\ \text { SCY } & 248936 & 776 & 249712 & 23 & 1.3 & 23.1 & 99.7 & 47.3 \\ \text { PH } & 433 & 53.1 & 486.1 & 16.2 & 5.7 & 17.2 & 89.1 & 31.5 \\ \text { PP } & 20056171 & 311487 & 20367658 & 13.9 & 1.7 & 14 & 98.5 & 28.5 \\ \text { MP } & 0.6 & 0.2 & 0.8 & 36.6 & 18.3 & 40.9 & 79.9 & 67.4 \\ \text { SP } & 11.4 & 0.2 & 11.6 & 17.5 & 2.5 & 17.6 & 97.9 & 35.6 \\ \text { BW } & 0.2 & 0.0 & 0.2 & 13.2 & 1.8 & 13.3 & 98.2 & 27.0 \\ \text { BP } & 13.6 & 0.1 & 13.7 & 16.2 & 1.6 & 16.3 & 99.0 & 33.2 \\ \text { SL } & 1.2 & 0.1 & 1.3 & 3.9 & 0.9 & 4.0 & 94.7 & 7.9 \\ \text { FS } & 2.5 & 0.1 & 2.6 & 5.7 & 1.3 & 5.8 & 95.3 & 11.4 \\ \text { LP } & 1.6 & 0.1 & 1.7 & 3.2 & 0.7 & 3.3 & 95.1 & 6.4 \\ \text { MV } & 0.2 & 0.0 & 0.2 & 9.9 & 1.7 & 10.1 & 97.2 & 20.1 \\ \text { UI } & 2.3 & 0.1 & 2.4 & 1.9 & 0.4 & 1.9 & 95.4 & 3.8 \\ \text { SI } & 1.0 & 0.1 & 1.1 & 13.1 & 3.0 & 13.4 & 95.1 & 26.3 \\ \text { LI } & 0.2 & 0.0 & 0.2 & 14.7 & 3.1 & 14.9 & 95.9 & 29.6\end{array}$

SCY: Seed cotton yield; PH: Plant height; PP: Plant population; MP: Monopodia plant ${ }^{-1}$; SP: Sympodia plant ${ }^{-1}$; BW: Boll weight; BP: Bolls plant ${ }^{-1}$; SL: Staple length; FS: Fibre strength; LP: Lint \%; MV: Micronaire value; UI: Uniformity index; SI: Seed index; LI: Lint index.

Principle component analysis (PCA)

To explore the momentous variation among sixty-four upland cotton germplasm, principle component analysis was used on collected mean data of fibre quality, yield and yield related attributes simultaneously ( $\mathrm{Ta}-$ ble 3). Out of fourteen principle components (PCs), five principle components revealed Eigenvalue $>1$ and $78.66 \%$ of cumulative variability for the attributes under examination. The PC I depicted 5.206 eigen value and $37.19 \%$ variability. The germplasm in PC I exhibited positive effects for seed cotton yield (0.412), lint index (0.397), seed index (0.395), bolls plant ${ }^{-1}(0.362)$ and sympodia plant ${ }^{-1}(0.354)$ while negative effects for number of monopodia plant ${ }^{-1}(-0.193)$ and micron aire value $(-0.145)$. The PC II revealed 1.811 eigen value and $12.94 \%$ of variability. The germplasm in PC II showed positive values for plant population (0.486), fibre strength (0.485), plant height (0.405) and uniformity index (0.389) while negative values for boll weight $(-0.342)$, sympodia plant ${ }^{-1}(0.131)$ and bolls plant ${ }^{-1}(-0.126)$. The PC III depicted 1.627 ei- $^{-}$ gen value and $11.621 \%$ of variability. The germplasm in PC III presented positive results for plant population (0.475), plant height (0.217) and lint \% (0.208) while negative results for staple length $(-0.457)$, fibre strength $(-0.370)$ and monopodia plant ${ }^{-1}(-0.368)$. The PC IV revealed 1.344 eigen value and $9.601 \%$ of variability. The germplasm in PC IV exhibited positive effects for lint \% (0.510) and staple length (0.252) while negative effects for micronaire value March 2018 | Volume 34 | Issue 1 | Page 132 
Table 3: Eigenvalues, percentage of variability, cumulative variability and attributes that contributed towards principle components.

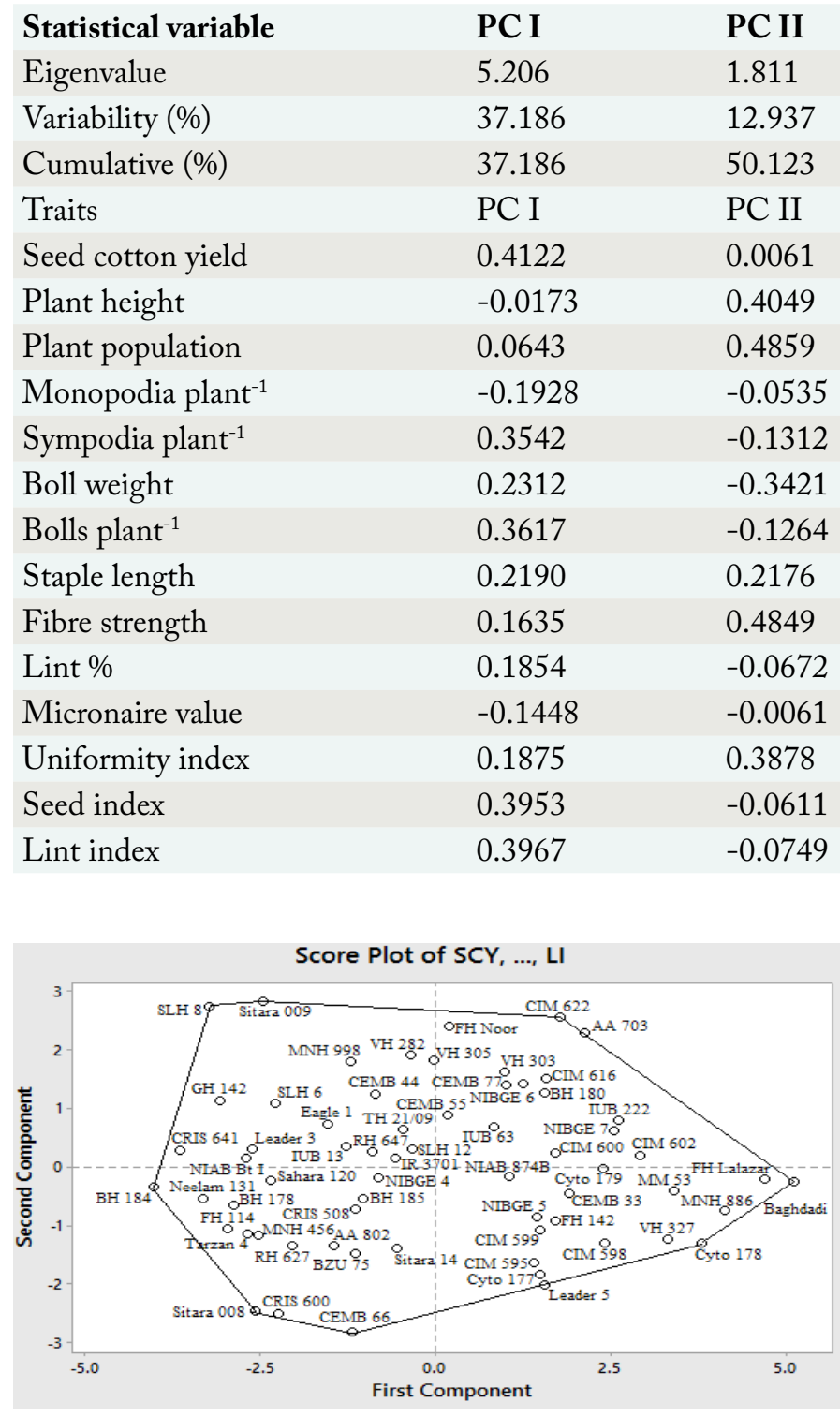

Figure 1: Score plot using mean data of sixty-four cotton germplasms.

(-0.634) and plant height (-0.328). The PC V depicted 1.025 eigen value and $7.319 \%$ of variability. The germplasm in PC $\mathrm{V}$ presented positive values for boll weight (0.546), Micronaire value (0.284) and lint \% (0.262) while negative values for sympodia plant ${ }^{-1}$ $(-0.434)$ and bolls plant ${ }^{-1}(-0.433)$.

\section{Score plot}

The score plot also known as polygon produced in principle components analysis diversified the sixty-four germplasm based on their genetic pattern (Figure 1). Baghdadi, CIM 622, SLH 8, BH 184, Sitara 008, CEMB 66, Leader 5, Cyto 178, FH Lalazar, CRIS 600, AA 703 and Sitara 009 were present at the vertex of polygon and resulted as most divergent germplasm. On the other hand, some germplasmwas present very close to the origin of polygon and sup-

$\begin{array}{lll}\text { PC III } & \text { PC IV } & \text { PC V } \\ 1.627 & 1.344 & 1.025 \\ 11.621 & 9.601 & 7.319 \\ 61.744 & 71.345 & 78.664 \\ \text { PC III } & \text { PC IV } & \text { PC V } \\ 0.1310 & -0.1056 & -0.0059 \\ 0.2169 & -0.3284 & -0.0591 \\ 0.4747 & 0.1035 & -0.1006 \\ -0.3680 & -0.0948 & -0.1256 \\ -0.1309 & -0.2005 & -0.4345 \\ -0.1213 & -0.1779 & 0.5465 \\ -0.1126 & -0.1555 & -0.4333 \\ -0.4571 & 0.2524 & 0.1123 \\ -0.3698 & 0.0165 & 0.0321 \\ 0.2078 & 0.5096 & 0.2617 \\ 0.1201 & -0.6336 & 0.2844 \\ -0.2394 & -0.1693 & 0.3414 \\ 0.1746 & -0.1041 & 0.0563 \\ 0.1984 & 0.0251 & 0.1121\end{array}$

posed as being genetically similar and minimum genetic divergence due to their narrow genetic bases. IR 3701, SLH 12, NIBGE 4, BH 185, CRIS 508, RH 647, TH 21/09, CEMB 55, IUB 63 and NIAB 874B found closer to the origin of polygon, hence exhibited less genetic diversity and breeding importance for future breeding programs.

Sixty four cotton germplasm were evaluated for genetic diversity, highly significance variation were observed among the germplasm for all studied attributes. Such high magnitude of variation among germplasm is significant indicator for plant breeder to improve various attributes in future breeding programs (Abbas et al., 2013). The GCV and PCV estimates were observed highest and mostly at par with each other while ECV estimates were very less, depicted that the studied attributes are genetically controlled having very less influence of the environment. These results were in close accordance with the previous findings of Ahsan et al. (2015) and Reddy and Reddy (2016), who also reported genetic influence of various attributes with less environmental effects. Similarly, the heritability estimates were found higher for all the attributes which further confirmed that all the studied attributes were under genetic control. In addition to higher heritability, the expected genetic advance was also higher. Higher genetic advance coupled with higher heritability might be due to the March 2018 | Volume 34 | Issue 1 | Page 133 
additive genetic effects for the studied attributes ( $\mathrm{Ab}$ bas et al., 2013; Vineela et al., 2013).These estimates help plant breeder in effective varietal selection based on all studied attributes in early generations for future cotton improvement programme. Previously, Dhivya et al. (2015) and Shao et al. (2016) also found the preponderance of additive genetic effects for various attributes, which confirms the present findings.

In principal component analysis, the most frequently used criteria for finding principle components is the eigenvalue-one criterion, also termed as the Kaiser criterion (Kaiser, 1960). Through this method, we maintain and analyse any component with an eigenvalue $>1$. Out of fourteen principle components, five principle components were depicted eigen value > 1and cumulative variability of $78.66 \%$ for all the attributes. The PC I and PC II contributes about 50.1\% of cumulative variability. The attributes of significance depicted in PC I and PC II were seed cotton yield, sympodia plant $^{-1}$, bolls plant ${ }^{-1}$, lint index, seed index and plant population expressed great contribution towards cumulative variability. These attributes should have bestowed special emphasis for cotton improvement in future breeding program. Previous findings of these attributes depicting their contribution towards cumulative variability and future cotton improvement programs were also reported by Saeed et al. 2014b, Kaleri et al. 2015 and Latif et al., 2015.

Baghdadi, CIM 622, SLH 8, BH 184, Sitara 008, CEMB 66, Leader 5, Cyto 178, FH Lalazar, CRIS 600, AA 703 and Sitara 009 were found as most genetically diverse germplasm. The germplasms could be utilized in future improvement program to broaden the genetic base through various breeding programs. The score plot scattered the germplasm based on the existence of significant genetic variation (Liaqat et al., 2015). The distance from the origin of plot and germplasm displayed the level of genetic divergence of germplasm i.e., greater distance showed significance diversity among germplasm and vice versa (Rana et al., 2013). Genetic diversity among germplasm may not rely only on their geographical distribution but also on numerous factors like environmental variability, exchange of hereditary material, genetic drift and natural and artificial selection (Bates et al., 1973). The results of present experiment were in greater accordance with Latif et al. (2015) and Khan et al. (2015).

\section{Conclusions}

The estimates of genotypic and phenotypic coefficient of variation were examined highest and mostly at par with each other while environmental coefficient of variation was very less, revealed that all the studied attributes were genetically controlled having very less influence of the environment. Out of fourteen principle components, five components were depicted eigen value $>1$ and cumulative variability of $78.66 \%$ for allthe studied attributes. The PC I and PC II contributes about $50.1 \%$ of cumulative variability. Baghdadi, CIM 622, SLH 8, BH 184, Sitara 008, CEMB 66, Leader 5, Cyto 178, FH Lalazar, CRIS 600, AA 703 and Sitara 009 were found as most genetically diverse germplasm. These most diverse germplasms could be utilized in future cotton improvement programme.

\section{Author's Contibution}

Syed Asif Imran Shah: Conducted experiments, collected data and wrote the paper.

Shah Jehan Khan: Designed the experiments and provided technical supervision and guidance.

Kalim Ullah: Provided overall guidance, supervision and help in write up of discussion and references.

Obaid Ullah Sayal: Did statistical analysis and wrotematerials and methods.

\section{References}

Abbas, H.G., A. Mahmood and Q. Ali. 2013. Genetic variability, heritability, genetic advance and correlation studies in cotton (Gossypium birsutum L.). Int. Res. J. Microbiol. 4(6): 156161.

Ahmad, R.I., S. Liaqat, E. Noor, A. Qayyum, A. Irshad, A. Hussain, G. Ahmed, A. Karim and S. Mahmood. 2015. A multivariate analysis approach for evaluating diverse germplasm of cotton (Gossypium hirsutum L.) for seed and fibre characteristics. Basic Res. J. Agric. Sci. Rev. 4(6): 164-171.

Ahsan, M.Z., M.S. Majidano, H. Bhutto, A.W. Soomro, F.H. Pahnwar, A.R. Channaand and K.B. Sial. 2015. Genetic variability, coefficient of variance, heritability and genetic advance of some Gossypium hirsutum L. accessions. J. Agric. Sci. 7(2): 147-151. https://doi.org/10.5539/jas. v7n2p147

Ali, M.A. and I.A. Khan. 2007. Assessment of genetic variation and inheritance mode in some metric traits of cotton (Gossypium birsutum L.). 
J. Agric. Soc. Sci. 4(3):112-116.

Bates, L.S., R. Waldren and I. Teare. 1973. Rapid determination of free proline for water-stress studies. Plant Soil. 39(1): 205-207. https://doi. org/10.1007/BF00018060

Burton, G.W. 1952. Quantitative inheritance in grasses. Proceedings of the sixth International Congress. pp: 277-283.

Dhivya, R., P. Amalabalu, R. Pushpa and D. Kavithamani. 2014. Variability, heritability and genetic advance in upland cotton (Gossypium birsutum L.). Afr.J. Plant Sci. 8(1): 1-5. https:// doi.org/10.5897/AJPS2013.1099

Falconer, D. S. 1989. Introduction to quantitative genetics (3rd ed.). Logman Scientific and Technical, Logman House, Burnt Mill, Harlow, Essex, England.

Haidar, S., M. Aslam, M.U. Hassan, H.M. Hassan and A. Ditta. 2012. Genetic diversity among upland cotton genotypes for different economic traits and response to cotton leaf curl virus (CLCV) disease. Pak. J. Bot. 44(5): 1779-1784.

Hanson, C., H. Robinson and R. Comstock. 1956. Biometrical studies of yield in segregating populations of Korean Lespedeza. Agron. J. 48(6): 268-272. https://doi.org/10.2134/agronj1956. $00021962004800060008 x$

Kaiser, H.F. 1960. The application of electronic computers to factor analysis. Educ. Psychol. Meas. 20: 141-151. https://doi. org/10.1177/001316446002000116

Kaleri, A.A., S.Y. Rajput, G.A. Kaleri and J.A. Marri. 2015. Analysis of Genetic diversity in genetically modified and non-modified cotton (Gossypium birsutum L.) genotypes. J. Agric. Vet. Sci. 8(12): 70-76.

Khan, F.Z., S.U. Rehman, M.A. Abid, W. Malik, C.M. Hanif, M. Bilal, G. Qanmber, A. Latif, J. Ashraf and U. Farhan. 2015. Exploitation of germplasm for plant yield improvement in cotton (Gossypium hirsutum L.). J. Green Physiol. Genet. Genom. 1(1): 1-10.

Latif, A., M. Bilal, S.B. Hussain and F. Ahmad. 2105. Estimation of genetic divergence, association, direct and indirect effects of yield with other attributes in cotton (Gossypium bitsutum L.) using biplot correlation in and path coefficient analysis. Tropical Plant Res. 2(2): 120126.

Liaqat, S., R.I. Ahmed, S. Ahmad, M. Bilal, A. Ka- rim, A. Qayyum, R.T. Ahmed and M. Rafiq. 2015. Evaluation of diverse germplasms of cotton (Gossypium birsutum L.) for yield and fibre attributes by multivariate analysis approach. J. Agric. Sci. Rev. 4(5): 146-150.

Lush, J.L. 1940. Intra-sire correlation and regression of offspring on dams as a method of estimating heritability of characters. Proc. Am. Soc. Anim. Prod. 33:293-301.

Rana, R.M., S. Rehman, J. Ahmad and M. Bilal. 2013. A comprehensive overview of recent advances in drought stress tolerance research in wheat (Triticumaestioum L.). Asian J. Agric. Biol. 1(1): 29-37.

Rehman, S., M.A. Abid, M. Bilal,J. Asharaf, S. Liaqat, R.I. Ahmad and G. Qambar. 2015. Genotype by trait analysis and estimates of heritability of wheat (Triticumaestivum L.) under drought and control conditions. Basic Res. J. Agric. Sci. Rev. 4(4): 127-134.

Reddy, K.B. and V.C. Reddy. 2016. Genetic variability and heritability in upland cotton (Gossypium hirsutum L.). Int. J. Agric. Sc. Vet. Med. 4(3): 17-21.

Saeed, F., J. Farooq, A. Mahmood, T. Hussain, M. RiazandS. Ahmad. 2014a. Genetic diversity in upland cotton for cotton leaf curl virus disease, earliness and fibre quality. Pak. J. Agric. Res. 27(3): 226-236.

Saeed, F., J. Farooq, A. Mahmood, M. Riaz, T. Hussain andA. Majeed. 2014b. Assessment of genetic diversity for cotton leaf curl virus (CL$\mathrm{CuD}$ ), fibre quality and some morphological traits using different statistical procedures in Gossypium hirsutum L. Aust. J. Crop Sci. 8(3): 442-447.

Shao, D., T. Wang, H. Zhang, J. Zhu and F. Tang. 2016. Variation, heritability and association of yield, fiber and morphological traits in a near long staple upland cotton population. Pak. J. Bot. 48(5): 1945-1949.

Steel, R.G.D. and J.H. Torrie. 1996. Principles and procedures of statistics: A biometrical approach, $3^{\text {rd }}$ edn. McGraw-Hill, New York.

Vineela, N., J.S.V.S. Murthy, P.V. Ramakumar and S.R. Kumari. 2013. Variability studies for physio morphological and yield components traits in American cotton (Gossypoum birsutum L.). J. Agric. Vet. Sci. 4(3): 07-10. 